ARTÍCULOS/ARTICLES 



\title{
THE MISSIONARY PURPOSE OF NICHOLAS OF CUSA'S CRIBRATIO ALKORANI
}

\author{
Pim Valkenberg \\ The Catholic University of America
}

\begin{abstract}
This article discusses the final purpose of the Cribratio Alkorani by Nicholas of Cusa. He offered it to pope Pius II as an instrument for the conversion of the Muslims. In conversation with Juan de Segovia, Nicholas developed the idea to «show the truth of the Gospel from the Qur'an» by giving a theological interpretation of this book that remained faithful to the principal tenets of the Christian faith while at the same time doing justice to the God-centeredness of the Qur'an.
\end{abstract}

\section{Keywords}

Qur'ān; Gospel; mission; interpretation; Christ

Among the many works written by Nicholas of Cusa, his Cribratio Alkorani or «Sifting of the Qur'ān» stands out as one of the most enigmatic treatises. His discussion of the book that Muslims consider the foundation of their religion revealed by God to the prophet Muhammad is so extensive and detailed that this work can legitimately be considered as a precursor of the contemporary genre of comparative theology. At the same time, Cusanus seems to oscillate between different approaches to this book and its authorship, and therefore his work can be characterized differently as a bridge between Christianity and Islam or as a traditional piece of Christian apologetics. In this article, I will discuss the missionary purpose of the Cribratio as a work that tries to show how the Qur'ann contains the truth of the Gospel, so that it can be used to convince Muslims of the truth of Christianity. It does so, however, in a way that is respectful of the God-centeredness of the Qur'ān to such an extent that it can indeed be used as a precursor to contemporary Christian theological approaches to Islam.

My interest in Nicholas of Cusa started in an interreligious context when I was asked to participate in a dialogue event in Tantur near Jerusalem on the 
topic of «Learned Ignorance» in 2007. ${ }^{1}$ Since I was one of the Catholic participants in this event with some knowledge of medieval theology, I thought it would be a good moment to start reading and analyzing Nicholas of Cusa. One of my colleagues at that time at the Radboud University of Nijmegen was Wilhelm Dupré who is a scholar of Nicholas of Cusa, and one of his students, Inigo Bocken, is now a professor at the Cusanus Hochschule in Bernkastel-Kues. ${ }^{2}$ So I was in some good company when I started my adventures by trying to connect the idea of docta ignorantia with the hermeneutical principle of pia interpretatio which I propose to translate as «faithful interpretation.» ${ }^{3}$ I am particularly interested in his approach to the Qur'ān since I have developed some knowledge of the Qur'ân myself as a Christian comparative scholar of Islam and the case can be made that Cusanus' approach to the Qur'ān has quite a bit in common with what is now called comparative theology. ${ }^{4}$ Even though my background is in Thomas Aquinas, I think that Nicholas of Cusa was able to approach Islam at a theological level, something that Thomas was not yet able to do, mainly because he noticed that because of the doctrine of tahrif («corruption») Muslims do not in fact accept the Christian Scriptures, so that there can be no proper theological communication, only philosophical communication. ${ }^{5}$ Against this background, it is interesting that Nicholas of Cusa apparently accepts the Qur'ān as basis for a Christological interpretation.

I have always been fascinated by some of the strong texts that the Qur'ān devotes to the idea that we can learn from the differences between us. In sūrat al-mä'ida (Q.5:48) the Qur'ān suggests that God could have created us as one community but instead chose to give each nation a law and a way. Nicholas of Cusa quotes this text as a Muslim argument, and in fact it forms, through its use in the Latin translation in the Toledan collection of the kitāb al-masă'il

${ }^{1}$ See Heft, J.L., Firestone, R., and Safi O., (eds.), Learned Ignorance: Intellectual Humility among Jews, Christians, and Muslims, Oxford - New York, Oxford University Press, 2011.

${ }^{2}$ Inigo Bocken published an article in a volume that I co-edited on Medieval dialogues: «Nicholas of Cusa and the Plurality of Religions,» in B. Roggema, M. Poorthuis, and P. Valkenberg (eds.), The Three Rings: Textual Studies in the Historical Trialogue of Judaism, Christianity, and Islam, Leuven, Peeters, 2005, pp. 163-180.

${ }^{3}$ Valkenberg, P., «Learned Ignorance and Faithful Interpretation of the Qur'an in Nicholas of Cusa (1401-1464)», in Learned Ignorance, op. cit., pp. 34-52.

${ }^{4}$ Cf. Schmidt-Leukel, P., Religious Pluralism \& Interreligious Theology, Maryknoll N.Y., Orbis Books, 2017, pp. 150-51.

${ }^{5}$ Valkenberg, P., «Can We Talk Theologically? Thomas Aquinas and Nicholas of Cusa on the Possibility of a Theological Understanding of Islam» in A.K. Min (ed.), Rethinking the Medieval Legacy for Contemporary Theology, Notre Dame IN, University of Notre Dame Press, 2014, pp. 131-66. 
attributed to Abdullah ibn Salam, one of the most important sources of Nicholas's famous expression, una religio in rituum varietate. ${ }^{6}$ It seems as if Nicholas is a precursor of present-day pluralists, but that would be an anachronistic reading. ${ }^{7}$ Yet it does show that Nicholas of Cusa really wanted to understand this Lex Mahumetorum, the source of the religion of the Muslims. While we will hear more about the way in which he studied the Qur'ān later in this volume, I will concentrate on the question as to why he did so. What motivated him to pay such detailed attention to the Qur'ān?

\section{Two Works, One Program}

It makes sense to start with a comparison between two of Cusanus' works, De Pace Fidei and the Cribratio Alkorani since both works can be connected with the «Fall of Constantinople» or, from a different perspective, the «Conquest of Istanbul» by Sultan Mehmet II in 1453. It seems that these two works do not only represent two very different literary genres but also different views on the possibility of interreligious collaboration, even though this is of course an anachronistic term. The work on the Peace of Faith, written immediately after the fall of Constantinople, is a work of fiction in which representatives of the different nations come together to discuss the possibility of a peaceful agreement. Nicholas might have taken as a frame of reference his own experiences at the Council of Basel (1431), and his attempts at the reunification between the Western and Eastern churches (1437) when Nicholas visited Constantinople. In the first section of De Pace Fidei he describes his own mood as «inflamed with zeal for God as a result of those deeds that were reported to have been perpetrated at Constantinople most recently and most cruelly by the King of the Turks». ${ }^{8} \mathrm{He}$ beseeches the heavenly king to «restrain the persecution that was raging more fiercely than usual on account of the difference of rite between the |two| religions» and in answer he receives the vision of this council on the peace of faith, which he wrote down so that it «might one day become known to those who have a say in these especially important matters». ${ }^{9}$ So we may think of De Pace Fidei as a

${ }^{6}$ Valkenberg, P., «Una Religio in Rituum Varietate: Religious Pluralism, the Qur'an, and Nicholas of Cusa», in I.C. Levy, R. George-Tvrtković, and D.F. Duclow (eds.), Nicholas of Cusa and Islam: Polemic and Dialogue in the Late Middle Ages, Leiden, Brill, 2014, pp. 30-48.

${ }^{7}$ Valkenberg, P., «One Faith, Different Rites: Nicholas of Cusa's New Awareness of Religious Pluralism», in P.C. Phan and J.S. Ray (eds.), Understanding Religious Pluralism: Perspectives from Religious Studies and Theology, Eugene OR, Pickwick, 2014, pp. 192-208.

${ }^{8}$ Nicholas of Cusa's De Pace Fidei and Cribratio Alkorani: Translation and analysis by Jasper Hopkins, Minneapolis, Arthur J. Banning Press, $2^{\text {nd }}$ ed. 1994, p. 33.

${ }^{9}$ Ibid., no.1. 
utopian dream that was meant to influence religious leaders to a more peaceful collaboration. Again, these are anachronistic terms but they show how Nicholas of Cusa and his De Pace Fidei may still be seen as an exceptional voice among Catholics, for instance by pluralist theologians Paul Knitter and Perry Schmidt-Leukel. ${ }^{10}$

In this respect, Cribratio Alkorani, written eight years later, seems like a totally different work. It is not a literary utopia but a very scholarly approach to the Qur'ān. Yet it is still part of the same trajectory that Cusanus started with the Peace of Faith: to reply to the Fall of Constantinople using words instead of the sword. As Marica Costigliolo summarizes: «Religious conflict is the central theme of De pace fidei, and all the efforts of the author are addressed to find peaceful solutions. The Cribratio Alkorani pursues the same goal, despite its profound difference from the point of view of style and contents». ${ }^{11}$ Recently, John Monfasani has argued that the usual positive reception of the utopian Peace of Faith and the more negative reception of the apologetic Sifting of the Qur'an should in fact be reversed: he characterizes the former as a not very successful thought experiment and the latter as a serious work of refutation. ${ }^{12}$

So what happened to explain the difference between the two works? We are fortunate to have some insights through the correspondence between Nicholas of Cusa and his contemporary Juan de Segovia who had met Nicholas at the Council of Basel. At the beginning they were both among the conciliarists but later Nicholas changed allegiance to the papal party. Nevertheless, they had enough in common to entertain a long friendship. A common interest in the Qur'ān was one of the driving forces shaping this friendship, since Anne Marie Wolf tells us that Juan borrowed a copy of the Qur'ān from Nicholas when they both were in Basel in $1437 .{ }^{13}$ When he heard of the fall of Constantinople, Juan de Segovia decided to react in a way similar to Nicholas of Cusa. He tried to find the best way toward peace with the Turks,

${ }^{10}$ Knitter, P., «Nostra Aetate: A Milestone in the History of Religions? From Competition to Cooperation» in C.L. Cohen, P.F. Knitter, and U. Rosenhagen (eds.), The Future of Interreligious Dialogue: A Multireligious Conversation on Nostra Aetate, Maryknoll N.Y., Orbis Books, 2017, pp. 45-58, at p. 45; P. Schmidt-Leukel, Religious Pluralism and Interreligious Theology, Maryknoll N.Y., Orbis Books, 2017, p. 151.

${ }^{11}$ Costigliolo, M., The Western Perception of Islam between the Middle Ages and the Renaissance: The Work of Nicholas of Cusa, Eugene OR, Pickwick Publications, 2017, p. 4.

${ }^{12}$ Monfasani, J., «Cusanus, the Greeks, and Islam», in T.M. Izbicki, J. Aleksander, and D.F. Duclow (eds.), Nicholas of Cusa and Times of Transition, Leiden, Brill, 2018, pp. 97-112, at 98, 104.

${ }^{13}$ Wolf, A.M., Juan de Segovia and the Fight for Peace: Christians and Muslims in the fifteenth century, Notre Dame IN, University of Notre Dame Press, 2014, p. 118. 
but he thought that a different attitude from the side of the Christians was necessary for that as well. Let me quote Anne Marie Wolf:

[he] shared with the more traditionally inclined humanists the view that the problem with the Turks was a religious one [...] but he rejected the crusade as the appropriate religious response and offered a different solution no less based on religious ideals. His primary aim was to convert fellow Christians to what he saw as greater faithfulness to the gospel, which would be manifested by seeking peace rather than war. ${ }^{14}$

On the one hand this sounds rather revolutionary. On the other, it is certainly not pacifism in the modern sense of the word, but peace as a means to convert the Muslims. So, Christians need to be converted to a peaceful solution, in order that the spirit of the Gospel be allowed to convert the Muslims to Christ. This is expressed in the title of a work that Juan de Segovia wrote in these days: De gladio divini Spiritus in corda mittendo Saracenorum («On putting the sword of the divine Spirit in the hearts of the Saracens»). I'm reminded here of another traditional humanist who trusted the power of the Gospel to prevail against the Turks: Erasmus of Rotterdam, writing after the siege of Vienna in $1529 .{ }^{15}$ On the one hand these authors can be called relatively enlightened and part of the humanistic tradition, yet on the other hand their goal is not universal world peace but the survival of the Christian tradition in a purified form. In other words: they want a reform of Christianity in order for the Muslims to be converted by the Gospel of Christ. John Monfasani argues that Nicholas of Cusa's missionary purpose clearly shines through in his letter to John of Segovia: It is a matter of discussion whether this is true for De Pace Fidei as well - I do think this is the case if one reckons with the utopian nature of the work. ${ }^{16}$ Now the interesting thing is that both Juan de Segovia and Nicholas of Cusa found it necessary to study the Qur'ān more closely in order to achieve this goal of converting Muslims to Christ. It would be interesting to compare the two scholars further on this point but that is not my task today, and elsewhere in this volume Jesse Mann will delve more deeply into Segovia's work. So let me go to the Cribratio Alkorani and try to explain why I think its purpose is missionary in nature.

${ }^{14}$ Ibid., p. 131.

${ }^{15}$ Erasmus's earlier writings, Dulce Bellum Inexpertis (part of his Adagia, published 1500) and his Querela Pacis (1517) may be compared to Nicholas of Cusa's De Pace Fidei, while his Utilissima Consultatio de bello Turcis inferendo (1530) may be compared to Juan's De gladio. In both cases the primary goal is that Christians live more in conformity with the Gospel.

${ }^{16}$ So I disagree with Wolf when she writes that in De Pace Fidei, Nicholas of Cusa went well beyond this aim and called for one universal religion (Juan de Segovia and the Fight for Peace, p. 139). 


\section{The Missionary Purpose of the Cribratio Alkorani}

At the beginning of his prologue, Nicholas makes clear that his primary goal is «to understand the book-of-law of the Arabs». ${ }^{17}$ In his possession, he had the translation commissioned by Peter the Venerable, abbot of Cluny, but he gave his copy to Juan de Segovia and tried to obtain better documentation when he was in Constantinople. He found a Qur'an in Arabic and another copy of the same Latin translation by Robert of Ketton, and he asked around to find out whether Christians in the East or in the West had written treatises against «these foolish errors». In the end, he decided to write his own book, applying his mind «to disclosing, even from the Koran, that the Gospel is true». ${ }^{18}$ At the end of this prologue, he repeats:

my intention is as follows: having presupposed the Gospel of Christ, to scrutinize the book of Muhammad and to show that even in it there are contained those |teachings| through which the Gospel would be altogether confirmed, were it in need of confirmation, and that wherever |the Koran| disagrees |with Christ|, this |disagreement| has resulted from Muhammad's ignorance and, following |thereupon|, from his perverse intent. ${ }^{19}$

A double observation needs to be made here. In the first place, Nicholas describes his search for proper documentation: he is looking for a good translation of the Qur'ān, supplemented by Christian polemics against this book. Besides John of Damascus and Thomas Aquinas, he noticed Ricoldo de Monte Croce's Contra Legem Sarracenorum and Juan de Torquemada's Contra Principales Errores Perfidi Machometi (1459). Moreover, he asked Dionysius the Carthusian (1402-1471) to write a work as well and send it - contra perfidiam Mahumeti - to the pope. In the midst of all these contrarian works, it is remarkable that Nicholas does not write against the Qur'ān or Muhammad,

${ }^{17}$ Translations are from Nicholas of Cusa's De Pace Fidei and Cribratio Alkorani: Translation and analysis by Jasper Hopkins. Original texts are quoted with book, chapter and paragraph numbers, and followed by page numbers from the critical edition in Nicolai de Cusa Cribratio Alkorani. Edidit commentariisque illustravit Ludovicus Hagemann. Opera Omnia, vol. 8, Hamburg, Felix Meiner, 1986. «Feci quam potui diligentiam intelligendi librum legis Arabum quem iuxta translationem per Petrum abbatem Cluniacensum nobis procuratam Basilieae habui... (prol.2)»

${ }^{18}$ «Ego verum ingenium applicui, ut etiam ex Alcorano evangelium verum ostenderem.» Prol. 4, ed. Hagemann, p. 7, transl. Hopkins, p. 76.

${ }^{19}$ Prol. 10: «Intentio autem nostra est praesupposito evangelio Christi librum Mahumeti cribrare et ostendere illa in ipso etiam libro haberi, per quae evangelium, si attestatione indigeret, valde confirmaretur, et quod, ubi dissentit, hoc ex ignorantia et consequenter ex perversitate intenti Mahumeti evenisse», ed. Hagemann, pp. 11-12, transl. Hopkins, pp. 78-79. 
but wants to separate the truth in this work from the errors. All of this shows an effort at scholarly approach, starting with the right texts. ${ }^{20}$ On the other hand, the purpose of this work is not purely academic but it is an apologetic or rather missionary purpose: to show the truth of the Gospel by means of the Qur'ān.

Let me pause here for a moment and explain why I assert that the Cribratio Alkorani has a missionary purpose. In his survey of Medieval Western Christian approaches to Islam, John Tolan writes about the difference between approaches to Islam in the twelfth century and before, and approaches in the thirteenth century and after. Of course this is a gradual shift, from largely "defensive reactions of Christians confronted by the power and prestige of the Muslim world» to "a significant effort to convert Muslims to Christianity through mission». ${ }^{21}$ The two Mendicant orders that originated in the thirteenth century each had their own way of approaching this mission: for the Franciscans, the missionary purpose was to travel to Muslim lands and preach the Gospel, often in hopes of martyrdom. For the Dominicans, such preaching should be preceded by study of languages and sources in order to be able to prove the superiority of Christianity to Muslims. One century later, Ramon Llull added his own voice to these missionary purposes, stressing the cogency of argumentation, rather than the use of authorities, as a way to convince Muslims. ${ }^{22}$ It might be my preoccupation with these Mendicant missionary methods, but I cannot help recognizing two of the central Mendicant elements: first, the idea of the truth of the Gospel that can be discerned in the Qur'ān; this matches with Nicholas's largely Christological approach in his Cribratio, and with his own conviction that showing this truth to Muslims will be sufficient to convert them. Second, the emphasis on learning as a prerequisite to such missionary work matches with the care that Nicholas of Cusa took to get the proper sources and an adequate translation of the Qur'ān.

${ }^{20}$ See Monfasani, «Cusanus, the Greeks, and Islam» op. cit., p. 107. The same is true for Juan de Segovia who even engaged a Muslim scholar, Yça Gidelli, to help him translating the Qur'ān. See Wolf, Juan de Segovia and the Fight for Peace, op. cit., p. 188. One is also reminded of Thomas Aquinas who is reported to have favored a proper text edition of John Chrysostom's sermons above the city of Paris.

${ }^{21}$ Tolan, J., Saracens: Islam in the Medieval European Imagination, New York, Columbia University Press, 2002, pp. 171, 172.

${ }^{22}$ Ibid., p. 172. For Llull's critique of Dominican methods and Raymond Martin's missionary method in particular, see S. Wiersma, Pearls in a Dunghill: The Anti-Jewish Writings of Raymond Martin O.P. (ca.1220 - ca. 1285), PhD dissertation, Tilburg University, 2015, pp. 114-20. 
Now let us look somewhat closer at how Nicholas of Cusa develops this idea of showing the truth of the Gospel from the Qur'ān. In my opinion, one of the most important elements in his hermeneutical approach is characterized by the famous words pia interpretatio («faithful interpretation») that sound almost like a principle of modern comparative theology: can we find an interpretation of a sacred text from another tradition that does justice to this tradition while at the same time remaining faithful to the principles of my own faith? In an earlier publication I have tried to elucidate the seemingly incoherent approach by Nicholas of Cusa in his Cribratio Alkorani as a combination of two hermeneutical approaches: on the one hand there is the traditional polemical approach that he inherited from most of the authors that he consulted in the Toledan collection and elsewhere. On the other hand there is the new desire to understand the «book-of-law of the Arabs» better by applying his faithful interpretation according to which the Qur'ān is true insofar as it confirms the truth of the Gospel. ${ }^{23}$ Walter Andreas Euler has observed that Nicholas of Cusa uses this hermeneutical principle of pia interpretatio only in the second book of his Cribratio Alkorani, and I think that this indicates the experimental nature of this hermeneutical approach; it is almost as if he looks how far he can get with this benevolent interpretation. ${ }^{24}$ The first text in which Cusanus applies this principle discusses the Trinity and states that «on a devout interpretation the Koran does not contradict [the doctrine of] the Trinity in the sense in which we who adhere to the Gospel speak of Trinity». ${ }^{25}$

The second text is related to the Qur'an's denial of the crucifixion of Christ. Cusanus explains that Muhammad in fact knew better, but decided not to affirm the crucifixion because this would be seen by the Arabs as detrimental to the honor of Christ as prophet. ${ }^{26}$ It is interesting that what

${ }^{23}$ Valkenberg, P., «Sifting the Qur'an: Two Forms of Interreligious Hermeneutics in Nicholas of Cusa», in: D. Cheetham, U. Winkler, O. Leirvik, and J. Gruber (eds.), Interreligious Hermeneutics in Pluralistic Europe: Between Texts and People, Amsterdam - New York, Rodopi, 2011, pp. 27-48.

${ }^{24}$ See Euler, W.A., «A Critical Survey of Cusanus's Writings on Islam» in Nicholas of Cusa and Islam, op. cit., pp. 20-29, at p. 27 nt. 26. «Benevolent interpretation» is Ludwig Hagemann's translation of pia interpretatio.

${ }^{25}$ Cribratio Alkorani II.1.86: "ostendamus Alkoranum pia interpretatione non contradicere Trinitati, modo quo nos de ipsa loquimur, qui evangelio inhaeremus.» Ed Hagemann, p. 72; transl. Hopkins, p. 115. «Devout interpretation» is Hopkins's translation of pia interpretatio.

${ }^{26}$ Cribratio alkorani II.13.124: «Certum est igitur quod Alkoranus illis Arabibus, si sine mysteriorum apertione Christum crucifixum aperte asseruisset, Christum in eorum mentibus non magnificasset. Voluit igitur secundum piam interpretationem occultare 
Cusanus ascribes here in a faithful interpretation of the Qur'ān comes close to the principle of a divine pedagogy that Christians have often applied to their reading of the old Testament. Nicholas of Cusa clearly makes a distinction between a level of understanding of the regular people and the understanding of wise people. He explicitly connects this with the idea of a faithful interpretation of the Qur'ān in the next text, in the context of the same discussion of Christ's crucifixion: «Hence it is evident according to a devout interpretation that the Koran meant to reveal these secrets only to the wise». ${ }^{27}$ Cusanus explains that if Muhammad had preached the Gospel, the Arabs would not have accepted it. Therefore, he told them that they were Ishmaelites, hoping to bring them to the Gospel: «Therefore Muhammad hid from the Arabs the secrets of the Gospel, believing that in the future |these secrets| could become known by the wise». ${ }^{28}$ In this interpretation the truth of the Gospel is indeed hidden in the Qur'ān and if a wise person approaches it with a faithful interpretation, he or she will be able to discover it. He adds that Jesus spoke similarly in parables. This does not only elucidate the title of the work, Cribratio Alkorani or the Sifting of the Qur'ān, but also the way in which Cusanus thinks it can be used to convert Muslims: if they can be shown that the truth of the Gospel is hidden in it, they will accept it.

So, this seems to be the strategy in the second book of the Cribratio. Yet toward the end of the book the strategy fails. What could be established when discussing Trinitarian theology and Christology collapses when discussing eschatology. So, in chapter 18 of the second book Cusanus says that he noticed, when reading the Qur'ān, how it uses likenesses (similitudines) to describe the day of judgment, paradise and hell, not dissimilar from what we read in the Gospel and the Old Testament. So - says Cusanus - «I told myself that this |befiguring in the Koran| could be excused because of the devout interpretation by the followers of |that| book». ${ }^{29}$ It is interesting to see how the pia interpretatio this time is not given by Christians but by followers of the Qur'ān. At the same time Cusanus seems to be upset by what he calls the

ipsis vilem mortem et quod adhuc viveret et venturus esse affirmare.» Ed. Hagemann, p. 99.

${ }^{27}$ Cribratio Alkorani II.12.119: «Unde patet secundum piam interpretationem Alkoranum haec secreta non nisi sapientibus voluisse revelare.» Ed. Hagemann, p. 95; transl. Hopkins, p. 129.

${ }^{28}$ Cribratio Alkorani II.12.120: «Quare Mahumetus ipsis secreta evangelii occultabat credens, quod sapientibus in futurum patescere possent.» Ed. Hagemann, p. 96; transl. Hopkins, p. 130.

${ }^{29}$ Cribratio Alkorani II.19.154: «intra me admittebam posse illa sequacium libri interpretatione excusari.» Ed. Hagemann, p. 125; transl. Hopkins, p. 147. 
vileness of the language about maidens and breasts and bestial copulation. ${ }^{30}$ Yet, at the end he admits that

God almighty willed that amid all these filthy and vain things, and things such as are abominable to the wise even among the Arabs, there also be inserted things in which the splendor of the Gospel was so contained as hidden that it would manifest itself to the wise if it were sought with diligent effort. $^{31}$

Three things are interesting in this quotation. In the first place, it seems to assume that God wanted to reveal the splendor of the Gospel even in the Qur'ān. In the second place, there is a kind of harmony between the wise among the Arabs - Cusanus clearly thinks about people such as Ibn Sina who give a spiritual interpretation of the likenesses - and the wise to whom God manifests the splendor of the Gospel if they study the Qur'ān with due effort (diligenti studio). Third, and finally, this diligent effort seems to be a parallel with the pia interpretatio mentioned before.

Thus far, I have mainly concentrated on book II of the Cribratio. One can make the case that this book forms the theological core of the work, discussing God and Trinity, Christ and salvation, resurrection and the afterlife. In this book, Nicholas gives his faithful interpretation of those creedal statements in which the Qur'ān seems to deviate from the truth of the Gospel, yet on a faithful interpretation can be shown to confirm this truth. The first book is of a more heresiological nature, following the speculation in the additional prologue, based on the Latin translation of al-Kindi's apology of Christianity, known as Rescriptum Christiani. This source tells us that Muhammad came under the influence of Sergius Bahira, a Nestorian monk, and converted to this form of Christianity. Yet the Qur'ān as Muslims have it was corrupted by two Jews after the death of Muhammad. This story combines two Christian counter-narratives: the first inverts the confirmation of Muhammad's prophethood by Bahira (associated with the «seal of prophethood») to show Nestorianism as a source of his heretical Christology. ${ }^{32}$ The second inverts the Islamic doctrine of tahrif or corruption, stating that

${ }^{30}$ Cribratio Alkorani II.19.154: «et stupebam de eo, quod saepe de puellis et earum papillis et bestiali concubitu in paradiso totiens replicavit.» Ed. Hagemann, p. 125.

${ }^{31}$ Cribratio Alkorani II.19.158: «Tamen omnipotens deus inter omnia illa spurca et vana et sapientibus enim Arabum abominabilia talia etiam inseri voluit, in quibus evangelicus splendor sic lateret occultatus, quod sapientibus diligenti studio quaesitus se ipsum manifestaret.» Ed. Hagemann, p. 128; transl. Hopkins, p. 149.

${ }^{32}$ On this, see Roggema, B. The Legend of Sergius Bahïrä: Eastern Christian Apologetics and Apocalyptic in Response to Islam, Dissertation, Rijksuniversiteit Groningen, 2007, pp. 14144. 
Jews and Christians changed the letter or the meaning of the revelation that they received from God. Eastern Christian sources such as al-Kindi state that it is not the Gospel but the Qur'ān that is corrupted under the influence of a Nestorian monk and two Jews who manipulated the text of the Qur'ān. ${ }^{33}$

Book three comes back to this theme of the ambiguities in the Qur'ān: on the one hand it seems to indicate that Christ is the greatest prophet, yet at the same time the Qur'ān tries to accommodate all different belief systems. In chapter three Cusanus tells us that Muhammad was not able to convince Jews and Christians of his prophecy and therefore ultimately justified himself by the use of the sword. ${ }^{34}$ So violence is the outcome of desperation because of the lack of truth. This becomes the main theme from chapter six onwards: despite the fact that God told him not to use violence, Muhammad has waged war and used violence against the unbelievers. Even though he knows that Christians have faith in the one God, he goes against them with the sword. At this point, Cusanus addresses Muhammad as follows: «Why, in Christians, do you oppose Christ to such an extent that you persecute those whom you do not deny to be saved through their own law? $»^{35}$ And a little further on: «Why do your followers persecute Christ in order to do away with His acquired people?» So, if you honor Christ, you cannot persecute his followers.

One would expect Nicholas of Cusa to continue in this vein when, at the end of the third book, he addresses the "Sultan of Babylon», imploring him to honor Christ and stop the violence. Yet he builds upon another similarity between Muhammad and his powerful follower: he was a Christian but became a Muslim in order to gain power. Elements of the additional prologue are mentioned once again here: Muhammad was deceived by the Jews, but it is possible to return to the true and pristine faith. Consequently, Nicholas asks the Sultan to honor Mary as Theotokos and to return to the original faith of the

${ }^{33}$ See Keating, S.T., «Manipulation of the Qur'an in the Epistolary Exchange between al-Hāshimī and al-Kindī» in M. Beaumont (ed.), Arab Christians and the Qur'an from the Origins of Islam to the Medieval Period, Leiden, Brill, 2018, pp. 50-65.

${ }^{34}$ Cribratio Alkorani III.3.168: «Postquam Mahumetus vidit se deficere in veritate et mendacia, quae ex testamento et evangelio allegabat, rudi et ignoranti populo non posse diu occultari Christianis et Iudaeis hoc verum negantibus, cum nec in ambobus nec in altero librorum allegatorum mentio fiat aut nominetur Mahumetus, ad arma se transtulit.» Ed. Hagemann, 136.

${ }^{35}$ Cribratio Alkorani III.6.180: «Cur Christo in Christianis in tantum adversaris, quod eos persequeris, quos non negas in sua lege salvari?» Ed. Hagemann, 145; transl. Hopkins, p. 160. 
Gospel. Rita George-Tvrtković is right that this is a somewhat strange but not unusual request. ${ }^{36}$ In the end, Nicholas says the following:

The law of the Arabs came as someone unwilling to consent unto the faith lof the Gospel], and it led the Arabs to the worship of one God; nevertheless, the Gospel was secretly approved |by the Koran|. And now it has pleased God that the approved Gospel, covered over in the Koran by many foolish things, should come to light, even as it was often approved of in |that| same book. In this way, those who previously were the most strongly resistant will be led from the law of the Arabs unto the Gospel - |led| for the glory of the Great God, the King of kings, the Creator and Lord of the universe. ${ }^{37}$

So, the final purpose of the Cribratio Alkorani is to serve as an instrument for the conversion of the Sultan, and, following him, the Muslims. Yet what makes this conversion possible is the power of truth that comes to light if the Qur'ān is read as leading toward the Gospel. This trust in truth as mode of conversion makes Nicholas of Cusa thoroughly modern yet at the same time thoroughly traditional. He is modern in his trust that «the truth will set you free» (John 8:32), and that it will work better to convert the Muslims than the sword. But maybe I should say that this is the typical approach of the scholar who thinks that people will recognize the truth when they see it. At the same time, his mentality is far away from the practical engagement of the missionary orders and congregations who went to the Muslim world in order to meet Muslims and engage with them. This reminds me of a remark made by Robin Vose in his book on Dominicans, Muslims and Jews in the Medieval Crown of Aragon, namely that the conversion of Muslims was an important goal for the Dominican friars, yet this was a theoretical goal in the sense that they were more likely to "preach about the errors of the 'infidel' (for the benefit of the faithful) than they were to preach to real Jews or Muslims.» ${ }^{38}$ In a similar way, Nicholas of Cusa wanted to convert Muslims by showing how the Qur'ān can be read in such a way that it confirms the truth of the Gospel, but he did not care to engage in practical efforts at conversion other than to include the letters to the Sultan of Babylonia and the Caliph of Baghdad in the third

${ }^{36}$ George-Tvrtković, R., Christians, Muslims, and Mary: A History, New York - Mahwah NJ, Paulist Press, 2018, p. 66.

${ }^{37}$ Cribratio Alkorani III.17.223: «venit lex Arabum quasi nolens consentire in ipsam et ad cultum eos unius dei approbato tamen occulte evangelio conduxit. Nunc placuit deo, quod approbatum evangelium coopertum multis ineptiis in Alkorano, quemadmodum approbatur saepe in eodem libro, in lucem veniat. Ita ducentur de lege Arabum ad evangelium prius fortissime resistentes ad gloriam magni dei, regis regum, creatoris et dominatoris universi.» Ed. Hagemann, 178; transl. Hopkins, p.181.

${ }^{38}$ Vose, R., Dominicans, Muslims and Jews in the Medieval Crown of Aragon, Cambridge, Cambridge University Press, 2009, p. 15. 
book. ${ }^{39}$ Even Pope Pius II (Aeneas Silvius Piccolomini) wrote a long letter to Sultan Mehmet in which he asked him to convert, but it seems that the Pope did not care to translate it and the Sultan never received it. ${ }^{40}$ Again, supporting fellow-Christians by telling them about the truth seems more important than actually preaching this truth to Muslims. ${ }^{41}$ Yet, at the same time, discovering the truth in the tradition of the other requires scholarly work and knowledge of the pertinent sources and languages. In order to convince the other, we need to try to gain a better understanding of that other. That is why the Cribratio Alkorani is a work of great scholarship despite its evident failure to convince the Sultan about the truth of the Gospel confirmed in the Qur'ân. That is also why it comes close to the modern academic field of comparative theology despite its clear apologetic purpose. ${ }^{42}$

Reading and studying Nicholas of Cusa's «Sifting of the Qur'ān» requires quite a bit of intellectual agility since the author changes perspectives quite often in his sometimes long-winded journey through the foundational text of the religion of Islam. Historically speaking the work never came close to fulfilling the goal for which Cusanus had written it, and it is useless as a manual for the conversion of Muslims. Yet it shows glimpses of excellence in its theological goal of proving the truth of the Gospel by sifting through the Qur'ān, and in its method of faithfully interpreting the text in a way that does justice to its God-centeredness while not deviating from the truth of God's self-revelation in Christ. It is this truth of God's revelation that is still at the center of respectful apologetics and dialogues between Christians and Muslims. The ultimate goal of these conversations is not to convert the other but to help one another to grow in learned ignorance about God.

Pim Valkenberg valkenberg@cua.edu

${ }^{39}$ It is not clear whether Nicholas thought that these were two different persons. He addresses the Sultan of Babylon (Soldanus de Babylonia) in book III chapter 17, and the Caliph of Baghdad (Califa de Baldach) in chapters 18-21.

${ }^{40}$ Wolf, Juan de Segovia and the Fight for Peace, op. cit., pp. 150-51.

${ }^{41}$ This is a general characteristic of apologetic writings: they are directed toward fellow-believers rather than to outsiders even though they are addressed to them. See Valkenberg, W.G.B.M., «Polemics, Apologetics, and Dialogue as Forms of Interreligious Communication between Jews, Christians and Muslims in the Middle Ages» in T.L. Hettma and A. van der Kooij (eds.), Religious Polemics in Context, Assen, Royal van Gorcum, 2004, pp. 376-83.

${ }^{42}$ Valkenberg, «Sifting the Qur'an: Two Forms of Interreligious Hermeneutics in Nicholas of Cusa», op. cit., p. 46. 
